\title{
accessibility of adolescent health services
}

\author{
S Richter \\ M Cur \\ Department of Nursing Science \\ University of Pretoria
}

\author{
"According to the \\ principles of primary \\ health care, a health \\ service should be \\ accessible to its user, in \\ this case the adolescent. \\ The service should be \\ within easy geographical, \\ functional, financial and \\ cultural reach of all \\ adolescents..."
}

\section{abstract}

Adolescents represent a large proportion of the population. As they mature and become sexually active, they face more serious health risks. Most face these risks with too little factual information, too little guidance about sexual responsibility and multiple barriers to accessing health care. A typical descriptive and explanatory design was used to determine what the characteristics of an accessible adolescent health service should be. Important results and conclusions that were reached indicate that the adolescent want a medical doctor and a registered nurse to be part of the health team treating them and they want to be served in the language of their choice. Family planning, treatment of sexually transmitted diseases and psychiatric services for the prevention of suicide are services that should be included in an adolescent accessible health service. The provision of health education concerning sexual transmitted diseases and AIDS is a necessity. The service should be available thought out the week (included Saturdays) and within easy reach.

It is recommended that minor changes in existing services be made, that will contribute towards making a health deliv. ery service an adolescent accessible service. An adolescent accessible health service can in turn make a real contribution to the community's efforts to improve the health of its adolescents and can prove to be a rewarding professional experience to the health worker.

\section{opsomming}

Adolossente verteenwoordig ' $n$ groot gedeelte van die bevolking. Soos wat hulle meer volwasse word en seksueel aktief raak, word jong mense meer blootgestel aan ernstige gesondheidrisiko's. Die meeste van hulle staar hierdie risiko's in die gesig met min feitelike inligting, te min leiding aangaande seksuele verantwoordelikheid en veelvuldige versperrings ten opsigte van die bekombaarheid van gesondheidsorg.

' $n$ Tipiese beskrywende en verklarende ontwerp is gebruik om die karakteristieke van 'n adolossente toeganklike diens te bepaal. Belangrike resultate en gevolgtrekkinge wat bereik is dui daarop dat die adolossent ' $n$ mediese dokter en geregistreerde verpleegkundige as deel van die gesondheidspan wat hulle behandel verkies, en in die taal van hulle keuse hanteer wil word. Dienste soos gesinsbeplanning, die behandeling van seksueel oordraagbare siektes en psigiatriese dienste vir die voorkoming van selfmoord is dienste wat ingesluit moet word in ' $n$ adolossente gesondheidsdiens. Die verskaffing van gesondheidsvoorligting i.v.m. seksueel oordraagbare siektes en VIGS is noodsaaklik. Die dienste moet tydens die week (insluitend Saterdae) beskikbaar wees en binne bereikbare afstand.

Dit word aanbeveel dat met klein veranderinge, bestaande gesondheidlewerings dienste adolossente toeganklik gemaak kan word. 'n Adolessente toeganklike diens kan 'n bydrae lewer tot die gemeenskap se pogings om die gesondheid van adolossente te verbeter en kan 'n professioneel verrykende ervaring vir die gesondneidswerker wees. 


\section{introduction}

Adolescents represent a large proportion of the population. As they mature and become sexually active, they face more serious health risks. They have the potential for considerable morbidity because of a high incidence of smoking, unwanted teenage pregnancies, sexually transmitted diseases, substance abuse, a high unemployment rate and accompanying violence. Most face these risks with too little factual information, too little guidance about sexual responsibility and multiple barriers to accessing health care. Nurses working in primary health care settings are in a unique position to establish trusting relationships and to confidentially explore the developmental concerns of young people (Brindis \& Sanghvi 1997: 567, McCauley, Salter, Kiragu \& Senerowitz 1995: 1 - 4).

According to the principles of primary health care, a health service should be accessible to its user, in this case the adolescent. The service should be within easy geographical, functional, financial and cultural reach of all adolescents (Dennill, King, Lock, Swanepoel 1995:6).

\section{problem statement and background of the study}

The adolescent years represent the period between the ages of 11 and 19 years. Late adolescence may last until the age of 22 years (Murray \& Zentner 1993: 372 ). These years involve much "growing up", with rapid physical growth and maturation. Less obvious, are the psychosocial events these adolescents encounter. Adjusting to a changing body, striving for independence from parents and establishing oneself in a group, are developmental priorities for any adolescent (Manning 1990: 823; Reif \& Elster 1998: 1).

The skills and tasks facing an adolescent include:

- acquiring good health habits,

- developing and acquiring the capacity for intimacy,

- $\quad$ developing peer group relationships with boys and girls,

- learning to develop a sexual identity,

- learning conflict resolution methods,

- learning how to have fun and develop a recreational interest by using a social support system,

- developing a personal value system, the ability to think concretely, operationally and abstractly, and direct ing their educational competencies towards academic and career goals,

- maintaining a balance between autonomy and interdependence, within an adult relationship with the parents, and

- developing a sense of commitment towards the community.

The stress of this development phase might prove detrimental if the child lacks support, social skills and adequate coping mechanisms (Reif \& Elster 1998: 1-2; Manning 1990: 823).

Adolescents are at risk from dying in car accidents, homicide, suicide and unintentional injuries. They are also at risk from sexually transmitted diseases, unplanned pregnancies, alcohol and drug abuse, depression and suicide (Cookfair 1996: 308). During clinic visits, health care providers have limited time with the adolescent client to address these issues. Developing a greater understanding of these issues will improve the intervention of the practitioner, in this case the nurses in primary health care settings (Hiltabiddle 1996: 61). Meeting these young adults' diverse needs, challenges parents, communities, health care providers as well as educators (Reif \& Elster 1998: 2). The question now arises of what the characteristics of an accessible adolescent health service should look like.

\section{purpose of the study}

The purpose of this study was to determine the characteristics of an accessible adolescent health care service from the viewpoint of an adolescent.

Figure $t$ shows that adolescents are exposed to specific health risks that are influenced by their developmental tasks

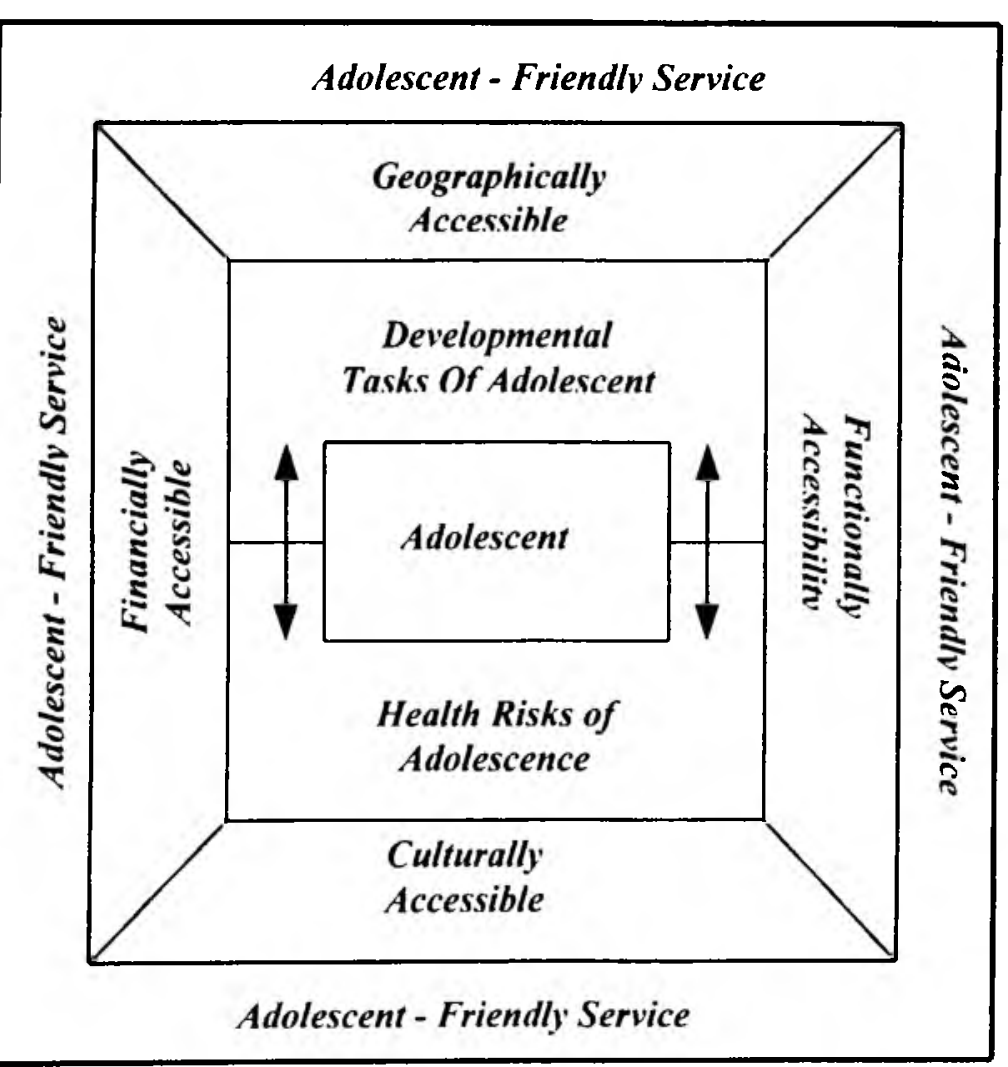

and that have to be taken into consideration when an accessible adolescent service is planned

The researcher aimed to determine the factors that have an influence on the financial, cultural, functional and geographical accessibility of an adolescent health care service.

\section{definitions}

Adolescence: The period from the beginning of puberty until maturity. The onset of puberty and maturity is a gradual process and variable among individuals. Thus, it is not practical to set an exact age or chronological limits in defining the adolescent period.

Accessibility: The accessibility of health services refers to the extent to which community health nursing services reach those people in need and how equitable the distribution are within the population (Stanhope \& Lancaster 1996: 238).

Geographical accessibility means that health services should be within a reasonable distance (the WHO suggests $5-10 \mathrm{~km}$ ) and that transport should be available. 
Functional accessibility means that the appropriate type of care should be available to meet the needs of the specific community.

Financial accessibility means that the levels of health care should be aligned to what the community and the country can afford. No person should be denied health care because of his or her inability to pay for it.

Cultural accessibility means that the health services should be rendered according to the cultural norms of the consumer (Dennill, King, Lock \& Swanepoel 1995: 6).

\section{research design}

A typical descriptive'and explanatory design was used. Explanatory studies provide an in-depth exploration of a single process or concept while a descriptive study examines the characteristics of a specific population (Brink \& Wood 1988: 100; Burns and Grove 1997: 251).

Data was collected by means of a questionnaire which was analysed, and conclusions were reached. The questionnaire consisted of multiple-choice and open-ended questions. In the multiple-choice questions, five options were given. The Likert-scale was used and the respondents had the choice between the following items: strongly disagree, disagree, uncertain, agree and strongly agree. Open questions were included at the end and it gave the respondents the opportunity of writing to express their own feelings (De Vos 1998: 160-161). A cover letter accompanied the questionnaire explaining the purpose of the study, the name of the researcher, the time it will require to complete the questionnaire and the institution supporting the study.

\section{validity and \\ reliability}

A thorough literature review was utilised to satisfy construct validity. The questionnaire was shown to professional persons with expertise in the fields of research methodology and adolescent health, with the purpose to increase its validity and reliability. The content validity was further increased by the presence of the researcher and a fieldworker during the completion of the questionnaire. The advantage of the presence of the researcher and a fieldworker, was that they could help with the interpretation of questions that were not understood. The questionnaire were administered in a consistent way, which is important for validity (Burns \& Grove 1993 : $373-374)$.

\section{sampling}

The sample consisted of $10 \%(N=80)$ of the pupils of the Bokamoso High School in Hammanskraal, a rural community $\pm 50 \mathrm{~km}$ north of Pretoria. Seaberg (1988: 254) and Grindell and Williams (1990:127) state that in most cases a $10 \%$ sample should be sufficient for controlling possible sampling errors. Convenience sampling was used. This entails using the most conveniently available people as study participants, which is useful in explanatory studies (Burn \& Grove 1997: 303). However, the problem with convenience sampling is that available subjects might be atypical representatives of the population, and self-selection generally leads to bias. This could have influenced the results of this study. Had the study been expanded to a larger population, simple random sampling would have been a better option (Polit \& Hungler 1997: 226 - 227).

\section{data analysis}

Descriptive statistics were used to analyse the data. Meas- ures of central tendencies were used. Nominal data was organised by the use of tables. It allowed visual comparison of summary data. The data was presented in the form of percentages.

\section{discussion of the findings}

\section{background information}

The age of the participants ranged from 15 to 24 years and the average age was 15,9 years. Forty eight percent of the participants were female and $52 \%$ male. Seven $(9 \%)$ of the female participants had previously been pregnant.

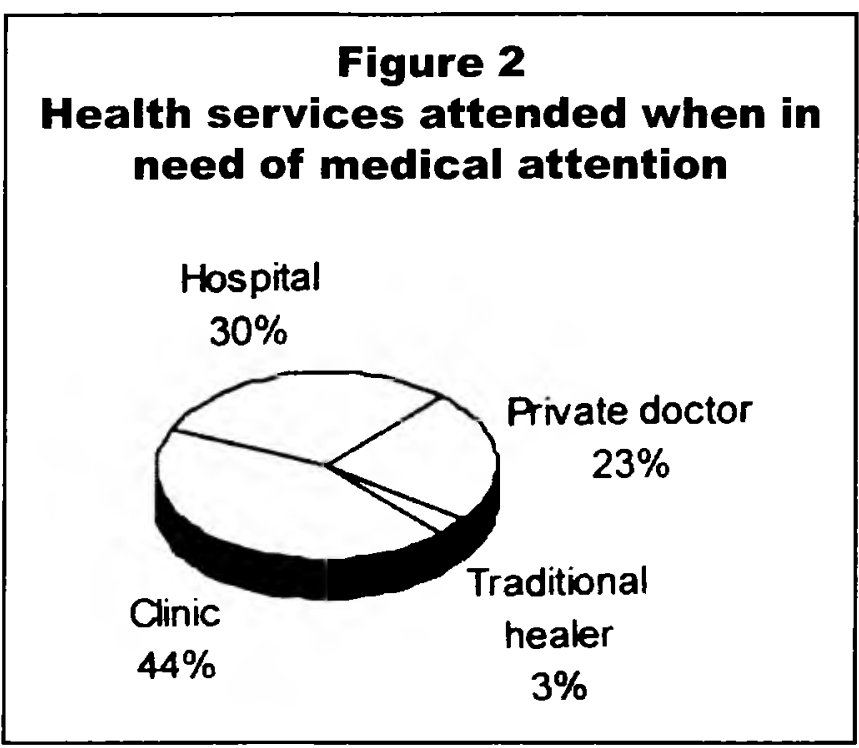

Figure 2 shows which type of health service the participants visited when in need of medical attention.

\section{functional accessibility}

The participants' preferences regarding certain characteristics of a functional, accessible health service, were determined. It was required of them to indicate their preferences regarding specific members of the health team, the age and gender of the health team worker, as well as the language in which they would prefer to be served.

The participants were also asked about the types of services they would like to see included in the adolescent health service. They had to indicate whether they felt the need for health education, and, if so, which aspects they would have liked to hear being addressed during such education. Lastly, they were asked to indicate the clinic hours and days of the week that would suit them best.

Member of the health team

Figure 3 indicates the participants' preferences for specific members of the health team to be present at the adolescent health service.

When asked, by means of an open-ended question, whether they would require any other member of the health team present, two participants indicated their need for a dentist and one indicated the need for a psychiatrist.

Age of the health team member

The majority of the participants $(85,9 \%)$ indicated that they would prefer health team members under the age of 34 years. 


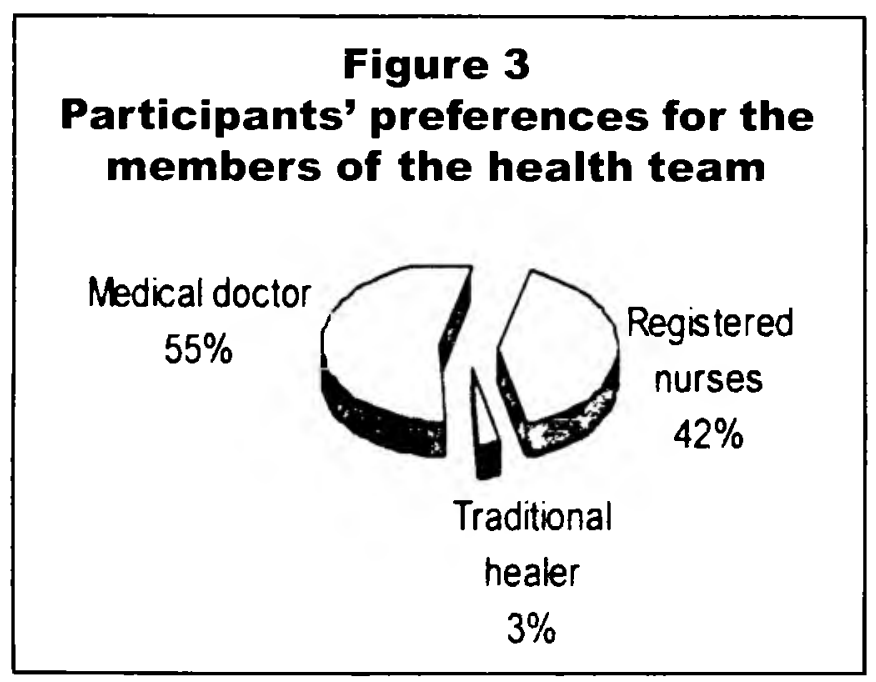

Gender of the health team member

Forty three percent of the participants indicated that they would prefer to be treated by health team members of the same gender as their own: $30,4 \%$ would prefer health team members of the opposite sex: and $26,6 \%$ were indifferent to the gender of the health team member.

\section{Language preference}

Most of the participants $(72,2 \%)$ indicated that they preferred to be served in the language of their choice, while $11,4 \%$ indicated that this made no difference to them.
Variety of services

Table 1 serves as an indication of the various types of services indicated by the participants as being necessary in an adolescent health service. Services catering for aspects regarding teenage sexuality, are in great demand. These include contraception and family planning, treatment of sexually transmitted diseases and antenatal care.

Resnick, Bearinger, Stark \& Blum (1994: 312) and Oakley, Fullerton, Holland, Arnold, France-Dawson, Kelly \& McGrellis (1995:312) confirm the importance of these findings. ACcording to Williams (1997: 173 - 185), the prevention of suicide in young people has become a priority for all health professionals.

Health education

Ninety six percent of the participants indicated their need for health education as part of the adolescent health service. Table 2 indicates, in order of priority, those topics requested by the participants.

Two participants indicated their need for information regarding tuberculosis and cancer.

\section{Clinic hours}

Regarding the preferred clinic hours, $97,1 \%$ indicated that they prefer hours of between 8 am and $4 \mathrm{pm}$. Participants were asked, in an open-ended question, whether they would like the service to be available at any other time, and 11 indicated that they would prefer a 24-hour service.

Figure 4 indicates the days of the week that participants would like the service to be available to them.

\section{Table 1}

\section{Indication of the various types of services indicated by the participants as being necessary in an adolescent health service}

\begin{tabular}{|l|l|}
\hline Type of servise & $\begin{array}{c}\text { Number of participants who want the } \\
\text { service available } \\
\text { (shown as percentages) }\end{array}$ \\
\hline Family planning services & $79 \%$ \\
\hline Services for the treatment of sexually transmitted diseases & $65 \%$ \\
\hline Psychiatric services for the prevention of suicide & $53 \%$ \\
\hline Service for the treatment of depression & $41 \%$ \\
\hline Abortion counselling service & $39 \%$ \\
\hline Service for the treatment of minor ailments & $35 \%$ \\
\hline Abortion clinics & $34 \%$ \\
\hline Psychiatric service for the prevention of violence & $34 \%$ \\
\hline Service for the treatment of substances abuse & $34 \%$ \\
\hline Service for the treatment of eating disorders & \\
\hline Obesity & \\
\hline Anorexia nevosa & $34 \%$ \\
\hline Bulimia & \\
\hline
\end{tabular}




\begin{tabular}{|ll|}
\hline Subject & $\begin{array}{l}\text { Amount of participants that need health } \\
\text { education on a specific subject }\end{array}$ \\
\hline Prevention of sexually transmitted diseases & $50 \%$ \\
\hline Acquired immune-deficiency syndrome (AIDS) & $35 \%$ \\
\hline Family planning methods & $28 \%$ \\
\hline Sexual development & $21 \%$ \\
\hline How to increase your self-esteem & $16 \%$ \\
\hline Healthy eating habits & $15 \%$ \\
\hline
\end{tabular}

\section{geographic availability}

Participants were asked to give an indication of the distance they are willing to travel to an adolescent health service and the time they are willing to spend on travelling. They were also asked to indicate their location of preference for the placement of the service.

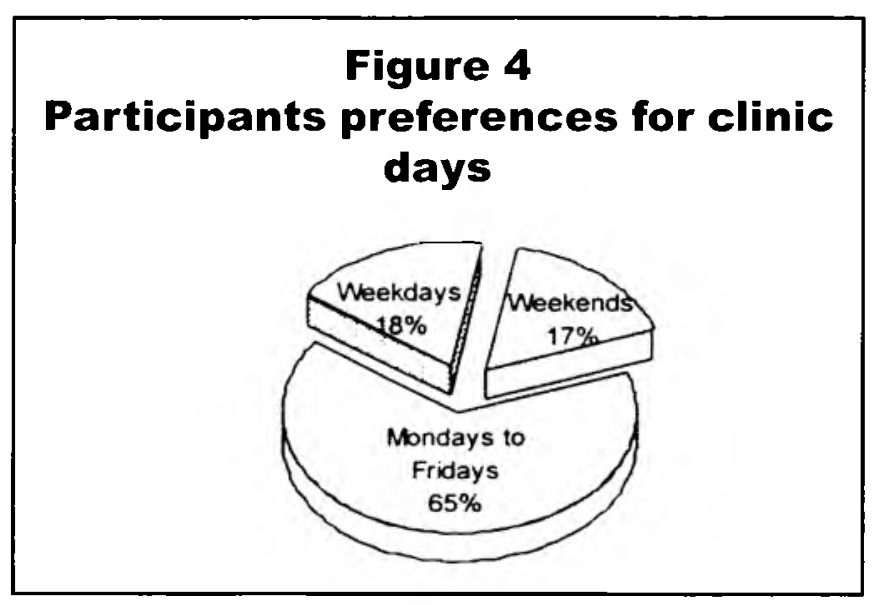

Distance

Figure 5 indicates that the majority of the participants would prefer not to travel very far to reach the adolescent health service.

\section{Travelling time}

As indicated by Table 3, the participants did not express a definite preference for a particular travel time, although $36,3 \%$ indicated that the adolescent health service should be within 1 to 14 minutes' reach from their homes. This result is surprising when it is considered that $61,5 \%$ of the participants do not want to travel more than $4 \mathrm{~km}$. The mode of transport should however be taken into account.

\section{Placement of the health service}

The participants indicated their preference for placement of the adolescent health service at school $(29,1 \%)$, at a clinic $(29,1 \%)$ or at a community centre $(24,1 \%)$. Only $10,1 \%$ preferred a hospital and $7,6 \%$ a youth centre as placement sites. According to Niclas, Johnson, Webber and Berenson (1997: 207 - 224) schools provide an excellent setting for introducing comprehensive health education and promotion, as a public health approach, to the general population.

\section{Figure 5 Travelling distance to an adolescent health service}

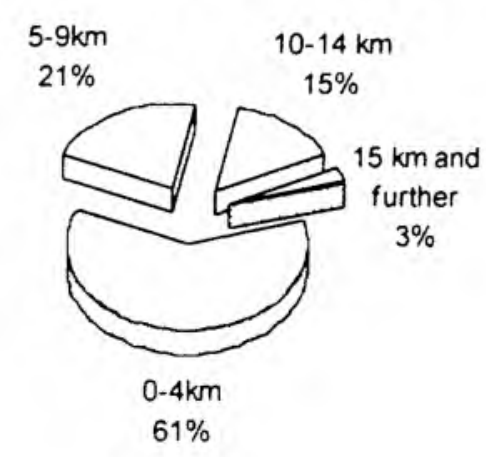

\section{financial accessibility}

The participants were asked to indicate how much they were willing to pay for an adolescent health service.

Figure 6 clearly shows that the majority of the participants are unwilling to pay more than R10,00 for a visit to the service. Their backgrounds should, however, be taken into consideration.

\section{cultural accessibility}

The participants had to indicate whether they prefer to be treated by health workers of the same cultural and religious standing as their own. In regard to culture, there was no meaningful preferences. Thirty Nine point 7 percent answered "yes", 30,8\% answered "no" and 29,5\% indicated that it did not matter. When asked about religion, the majority either answered "no" or had no preference. Only $19,7 \%$ answered "yes" to this question.

\section{adolescent-friendly health service}

The following open-ended question was included at the end of the questionnaire: "What do you see as an adolescentfriendly health service?" Twenty five percent of the participants indicated that the health workers should be friendlier. They also mentioned that the service should be more efficient and effective, and medication as well as a 24-hour helpline should be readily available. The participants also 
Table 3

\section{Travelling time to an adolescent health service}

\begin{tabular}{|l|c|}
\hline Travelling time to an adolescent health service & $\begin{array}{l}\text { Number of participants } \\
\text { (shown as percentages) }\end{array}$ \\
\hline $1-14 \mathrm{~min}$ & $36,3 \%$ \\
\hline $15-19 \mathrm{~min}$ & $21,3 \%$ \\
\hline $20-24 \mathrm{~min}$ & $11,3 \%$ \\
\hline $25 \cdot 29 \mathrm{~min}$ & $2,5 \%$ \\
\hline $30 \mathrm{~min}$ and more & $28,8 \%$ \\
\hline
\end{tabular}

\section{Figure 6 \\ Amount that participants are willing to pay for a visit to an adolescent health service}

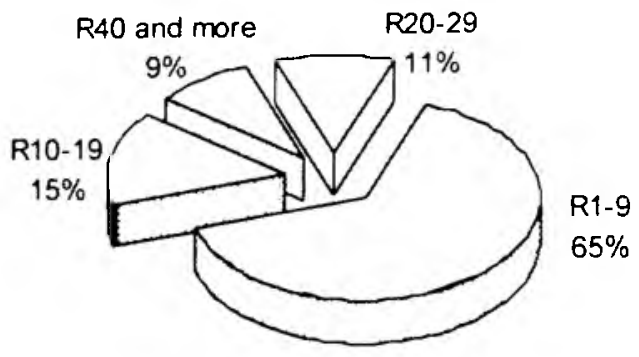

indicated that effective health education should form part of this service, especially with regard to the prevention of unwanted pregnancies, sexual problems and dependencyforming behaviour.

The need to teach adolescents on how to take responsibility for their own decisions was also expressed, as well as a need for guidance on how to be successful.

\section{conclusions}

It is apparent that the participants held certain preferences as to how an adolescent-friendly health service should look like. The results indicate that the participants view such a health service as follows:

- A medical doctor and a registered nurse should be included in the health team.

- The health workers should serve them in their language of preference.

- The following services should be provided:

- contraception and family planning

- treatment of sexually transmitted diseases

- $\quad$ psychiatric services for the prevention of suicide

- The provision of health education is a necessity.

- Health education regarding the prevention of sexu- ally transmitted diseases and HIV/AIDS is viewed as important.

- $\quad$ The service should be available throughout the week and should include Saturdays.

- The service should be within easy reach (no farther than $10 \mathrm{~km}$ ).

- The service may be located at a school, clinic or com munity centre and should be affordable.

\section{recommendations}

The participants were not representative of all adolescents in South Africa. Thus, the conclusions cannot be generalised. The researcher suggests that the study be expanded to include the urban adolescent. A larger sample should be used in order to attain a better representation of the country's youth.

The success of an adolescent-friendly health service will largely depend on how well the personnel can capitalise on their strategic position to reach adolescents, responds to their needs, and reduce barriers to care. With minor changes, an existing health service can be made into an adolescentfriendly health service. An adolescent-friendly health service can make a very real contribution to the community's efforts to improve the health of its adolescents, and can result in a rewarding professional experience to the health worker. 


\section{sources}

Brindis, C. D., \& Sanghvi, R. V. 1997. School-based health clinics: remaining viable in a changing health care delivery system. Annual Review of Public Health, 18: 567 - 587.

Brink, P.J., \& Wood, M.J. 1988. Basic steps in Planning Nursing Research. Boston: Jones and Bartlett Publishers.

Burns, N., \& Grove, S.K. 1997. The practice of nursing research: conduct, critique and utilisation. Philadelphia : W B Saunders Company.

Cookfair,J.M. 1996. Nursing Care in the Community. St Louis: Mosby.

Dennill,.K; King,L., Lock,M., \& Swanepoel,T. 1995. Aspects of Primary Health Care. Johannesburg: International Thomson Publishing Company.

De Vos, A.S. 1998. Research at grass roots. Pretoria: JL van Schaik.

Grindell, R.M., \& Williams, M. 1990. Research in social work: A primer. Itasca,IL: Peacock.

Hiltabiddle, S.J. 1996. Adolescent condom use, the health believe model and the prevention of sexual transmitted diseases. JOGNN, 25(1): 61-65.

Manning, M.I. 1990. Health Assessment of the Early Adolescent. Nursing Clinics of North America, 25 (4): 823 - 831.

McCauley, A.P., Salter,C., Kiragu, K., \& Senderowitz, J. 1995. Meeting the needs of young adults. Population reports-Series J: Family Planning Programs, (41): 1 - 43.

Murray, R.B., \& Zentner, J P. 1993. Nursing assessment and health promotion: strategies through the lifespan. Connecticut: Appleton \& Lange.

Nicklas,T.A., Johnson,C.C., Webber, L.S., \& Berenson,G.S. 1997. School-based programs for health-risk reduction. Annals of the New York Academy of Science, 817: 208 - 224.

Oakley,A., Fullerton,D., Holland,J., Arnold,S., France-Dawson, M., Kelley,P., \& McGrellis,S. 1995. Sexual health education interventions for young people: a methodological review. British Medical Journal, 64(2) : 310 - 306.

Polit,D.F., \& Hungler,B.P. 1997. Essentials of nursing research methods, appraisal, and utilization. Philadelphia: Lippincott.

Resnick, M.D., Bearinger, L.H., Stark,P., \& Blum, R.W. 1994. Patterns of consultation among adolescent minors obtaining an abortion. American Journal of Orthopsychiatry, $64(2): 310$ 360.

Reif, C.J., \& Elster, A.B. 1998. Adolescent preventive service. Primary Care, 15(1) : 1 - 19.

Seaberg, J.R. 1988. Utilizing sampling procedures. (/n Grindell, R.M. 1998. Social work reseach and evaluation, 3rd ed. Itasca,IL: Peacock, pp.240-257.

Stanhope,M., \& Lancaster,J. 1996. Community Health Nursing: promoting health of aggregates, families and individuals. St.Louis: Mosby.

Williams,K. 1997. Preventing suicide in young people: what is known and what is needed. Child: Care, Health and Development, 23(2): 173 - 185. 